\title{
A time to confess? An ecclesiology of vulnerability in light of \#metoo
}

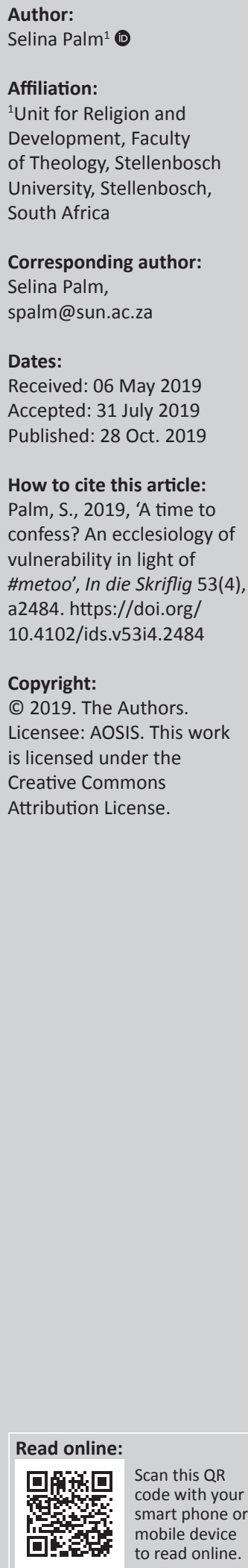

This article draws on Robert Vosloo's call for an 'ecclesiology of vulnerability' in order to bear faithful theological witness to a vulnerable God. He is concerned that prophetic witness avoids a cheap triumphalism and rediscovers painful solidarity with the crises of our times, embodies a hope grounded in lament and mobilises the vulnerable 'body' of the church to perform resistance-in-action. South Africa's kairos tradition of prophetic witness was addressed to the church, calling for a vulnerable self-critique that acknowledged its theological complicity in the face of the sin of apartheid and calling the churches beyond pious words to acts of embodied resistance. This article draws on this trajectory in light of the evidence regarding churches complicity in relation to sexual violence against vulnerable women and children. It explores the Dutch scholar, Leo Koffeman's claim of 2009 that the church is 'morally vulnerable' and that as a result, violence plays an ongoing role in its life. This institutional complicity needs to be acknowledged if authentic prophetic witness is to emerge from current places of lament. In this task, a 'pneumatology of vulnerability' may help disrupt abusive theological power-claims. Churches must risk admitting their own institutional vulnerability to embody public practices of confession and lament, if they are to refuse an ecclesiology of denial for one of disruption for the sake of justice. This is an essential theological task if they are to enable the vulnerable body of the church to admit \#metoo.

Keywords: Vulnerability; ecclesiology; sexual violence; \#metoo; body theology; churches; gender; theologies of liberation; feminist theology.

\section{Introduction}

In the 2013 film, Blue like Jazz, the conservative Christian protagonist, Don, finds himself immersed in a secular university in the USA, which ridicules and critiques the religious beliefs he grew up embracing. Over the year, he rejects much of what he used to believe, but by the end of the film he begins to find a different way to reconnect to Christian faith. We see him in a late scene unexpectedly anointed as the 'Pope' and asked to hear 'confessions' from the other atheist students as part of their annual rag week to mock religion. As he hears the embodied stories of covered up clerical sexual abuse that underpin the anger and pain of his friends, which has shaped their rejections of the church he has believed in all his life, his own understanding undergoes a radical shift. Instead of listening to individual confessions as the church representative who forgives from on high as expected, he uses the same confessional box to ask, confess and apologise to each of those wronged by the church to which he belongs, for the concrete systemic sins which it has committed, and for its misrepresentation of God. In this moment, I suggest he embodies an alternative church performance, grounded in lament and confession, as a form of prophetic witness to and by the church, in recognition of its own culpability, complicity, silence and failure to act as specific forms of moral vulnerability. It is this type of response that is urgently needed across church denominations throughout the world today, in light of the emerging evidence of ongoing sexual abuse of women and children within churches and the cover-up and silencing of victims.

The above performance, I want to suggest, revolutionises the protagonist's ecclesiology from a top-down understanding of the church as 'the body of' or the 'spotless bride of' Jesus Christ as a perceived perfect place offering forgiveness to many individual sinners. Instead it 'troubles', it presents the church as a place of ruins that often misrepresents God and has caused damage and scarred many human lives. This deep entanglement of the church in forms of violence should be ongoingly confessed by all who are participants in the church as an act of vulnerable public witness to the truth. This should not be through the merely abstract or pious rhetoric of 'we are all sinners', but through a radical liberating reform of all theological ecclesiologies that place topdown male power at its centre. While ethical ideals are clearly important for churches, idealistic 
understandings of the church itself can become complicit in turning a blind eye to its actual lived realities, and by perpetuating abusive images of the divine theologically that have been used to justify and cover-up human violence. I suggest that this offers an example of the need for painful solidarity with a specific crisis of our times, epitomised by the \#metoo movement. It seeks to embody a hope grounded in the concrete lament of sexual victims with its twin dimensions of sadness and anger. This can be done by mobilising the body of the church as a body that is itself complicit and therefore can be regarded as morally vulnerable to perform a disruptive form of resistance-in-action. In this way, this article will provocatively deepen and make specific Vosloo's threefold call for painful solidarity with the crises of our time: an embodied hope grounded in lament, and the need for churches to perform resistance-in-action in ways that recognise its own vulnerabilities. Vulnerability is often defined negatively as being synonymous with weakness or frailty. It comes from the Latin word for 'wound', as being open to the act of being hurt in physical, emotional or structural ways and the need for protection against this. However, it can also be regarded as an openness to moral temptation, for example 'he was vulnerable to bribery'. This includes not only its abilities to be wounded, but also to directly or indirectly wound others. This dimension of human vulnerability will be explored further here. This article sits within a trajectory of South African theologians such as Vosloo and Koopman who seek to reclaim the vulnerability of God, but adds a more critical feminist dimension to this line of thought.

\section{The church ${ }^{1}$ and \#metoo}

In the last few years, compelling evidence has mounted around the world regarding the systematic sexual abuse of people within the Christian church and their related institutions of care. Women and children have narrated disturbing historical and current examples of sexual abuse within religious spaces, as well as the systematic cover-up and silencing of these abuses (Palm 2019b; Ritchie 2018). In parts of Zimbabwe, research shows that self-styled Christian 'Prophets' even claim God's direct anointing to take girl children as their wives, supported by congregants (Le Roux \& Palm 2018; Progressio 2016). Investigations are underway around the world regarding accusations against both Catholic and Protestant wings of the church. Recent evidence exploring connections between faith and sexual violence against children, also suggests that the scale of institutional abuse is greater than we currently know (Rutledge \& Eyber 2019). A Royal Commission investigating allegations against the Salvation Army in Australia (Prosser 2016), and a five volume report in 2009 on Catholic-run institutions in Ireland (Halpin 2018) are two concrete examples of decades of abuse of the most vulnerable within church spaces, underpinned by

\footnotetext{
1.Smit (2007:61) points out that the expression the church can mean many different things and is a story of many stories. He points to three forms: the worshipping local things and is a story of many stories. He points to three forms. the worshipping local congregation, the institutional denominations within the ecumenical church, and the actions of individual believers in civil society. In this article, I focus on the institution of the church manifested in plural forms at local congregational level, including core theological beliefs and practices. I use a singular definition to emphasise the belief that the church is called to reflect unity.
}

institutional secrecy, cover-ups, a failure to act, the moving on of abusive religious leaders, a refusal to engage with legal systems, and the abuse of spiritual power (Yang 2019). What does it mean to start all theologising from this unpalatable reality? What sort of vulnerability is being laid bare here? Palm and Le Roux point to empirical research carried out by Le Roux in 2013 regarding the complicit role of churches in sexual violence across six South African communities ${ }^{2}$. They note that (Palm \& Le Roux 2019):

When asked to reflect on how their churches were responding to sexual violence, the participants were unanimous: very little. This is seen as a result of churches not seeing sexual violence as an issue it should be addressing, as it is only concerned with so-called 'higher' matters, such as prayer and Bible reading. According to the participants, churches do not take sexual violence seriously and do not apply the Bible contextually to the issue. Participants consistently spoke of the misogyny of churches and their theologies, their complicity not only in ignoring the reality and silencing those who speak out, but their own role in perpetration. According to the majority of participants, many church leaders were themselves guilty of perpetrating sexual violence. However, they remained unconfronted by the wider church leadership because these perpetrators were persons with authority. (p. 142)

Palm and Le Roux argue that churches can only have credibility to address sexual violence in communities if they also publicly confront and eradicate sexual violence in their own churches - requiring a paradigm shift in the mindset of many churches regarding how relationships between genders are understood. As one leader from Cape Town noted in the 2013 research, the perceived moral high ground of churches can mitigate against this engagement around sexual abuse, saying (Palm \& Le Roux 2019):

The church should be playing a big role, but it isn't always so. There is a big gap between community members and church members. Church members think they are perfect, they think they don't have to connect with community members. (p. 143)

Lived experiences of sexual abuse within churches continue to this day in South Africa. For example, in 2018 young women staged a protest at the Central Methodist Mission church in Johannesburg, because of the silence of church leaders in the face of reports of repeated sexual harassment by someone in a position of church authority. As one of the victims said after the protest in an interview with News24 (News24 2018), 'You call them tata [father] and they treat you like a piece of meat', saying that she had only gone public in the face of continued institutional refusals to act on her evidence from within the local church itself.

Allegations of sexual abuse have been reported within the Anglican church in South Africa, some going back decades. These have led South African Anglican archbishop, 2.This qualitative research on the role of Christian churches in sexual violence, was
conducted in six diverse communities in South Africa and it secured ethical
clearance from Stellenbosch University. Using questionnaires, in-depth interviews
and focus groups, it explored how community members understand and experience
sexual violence, and how churches are part of and responding to it. Le Roux's 2013 report is entitled, Sexual violence in South Africa and the role of the church. 
Thabo Makgoba, to publicly announce recent consultations, to strengthen procedures for dealing with sexual abuse across Anglican churches (Ritchie 2018). But promises have been made by churches on this issue before, as a form of emergency rhetoric in light of media scandals but have not yet been translated into sustained structural action. Will this be different? I suggest that \#metoo is a kairos moment - a moment of truth and judgement to which churches, in order to respond radically, will also have to reflect on their own identity. Out of this crisis may emerge a more truthful ecclesiology with a prophetic witness that enables more churches to confront and confess authentic repentance, and take steps to turn around as a form of metanoia that embodies the dialectic of cross and resurrection that is at the heart of its theological claims about life together.

It is from this concrete place of crisis that I engage Vosloo's call for a threefold approach to prophetic witness, which includes solidarity, imagination and performativity. His concern, with which I concur, is that an approach, which only sees prophetic witness as the bold and courageous speaking of truth to power, can become triumphalistic. To avoid this danger, Vosloo (2019) concludes that:

True prophetic speech results from solidarity with the times; it is born out of relational pain. True prophetic imagination is a hopeful imagination born from lament. And true prophetic performativity is marked by resistance in vulnerability. (p. 14)

Volsoo's article ends with some questions for Christian churches regarding a 'prophetic performativity where resistance is born out of vulnerability'. He (Vosloo 2019) asks:

Where are our bodies? With whom and how are we bodily present? How do we deal with our own vulnerability as a result of injustice and the abuse of power? Do we risk becoming vulnerable as a result of our solidarity with others in their precarity? (p. 13)

Vosloo points to South African theologian, Nico Koopman's (2008:240) ecclesiology of vulnerability as a potential resource, noting that for Koopman:

[V]ulnerability is not merely based on the vulnerable environment in which the church finds itself; rather, vulnerability is part of the essence of the church, since the church lives in solidarity with vulnerable human beings and within vulnerable eco-systems. The emphasis on vulnerability invites Christians and the church to witness with greater gospel integrity to the liberating logic of the reign of God. (Vosloo 2019:13)

I begin here where Vosloo ends: to suggest that a deepened reflection on an ecclesiology of vulnerability in relation to bodies is required in light of sexual abuses within the churches. Where is the body of the church in relation to this issue? Who is the 'we' that are called to be bodily present in light of this injustice? Is the body of the church willing to deal theologically with its own complicity in the face of the realities of institutional sexual injustice, abuse, silence and cover-up within its own ranks, and will the church risk experience vulnerability in so doing? The religious idea of the 'prophetic' voice as speaking truth to power has terrifying, tragic dimensions that require judgement and grace (Vosloo 2019). It is likely that this experience of church vulnerability to failure will be a terrifying, tragic experience for them to admit their weaknesses and failures as an institution, rather than succumbing to the ongoing desire to hold to an 'ecclesiology of denial'.

\section{Engaging an ecclesiology of vulnerability}

Reformed theologian, Koopman (2008), points to the need for the church to publicly admit its own frailties and vulnerabilities. He ties his recommendation of a vulnerable church to the notion of a vulnerable God to whom the church is called to witness, and he draws on the classic three roles for the church as vulnerable prophets, priests and kings. $\mathrm{He}$ calls the church to stand with the most vulnerable as the place where God stands, as part of a liberating Reformed tradition that draws on prophetic Calvinism and historical events in South Africa, such as the 1986 Belhar Confession, which called the church to public confession of the sin of apartheid (Koopman 2008:246). For Koopman, prophetic engagement involves both vision and critique, but also engages policy, models hope in action as royal servants, and builds empathy and solidarity as a priestly task. Koopman (2008) notes that:

... to be church in a vulnerable world is to be vulnerable church, not just because it contains vulnerable people but because vulnerability is part of the essence of the church. (p. 245)

I agree that acknowledging vulnerability is internally critical to ecclesiology, and not just a side-effect of inhabiting a vulnerable world. However, I remain concerned with the theological dangers of emphasising only an innocent vulnerability for the church in the name of divine vulnerability. This can position churches primarily as 'saviours' whose witness to vulnerability becomes a new way to model divine incarnation in a messy world. Vulnerability is framed 'a la Jesus' as entering a messy finite world to step perfectly into others' tragedies, rather than also as experiencing the full weight of human imperfections and the moral vulnerability to hurt, damage and destroy others' lives.

I have two concerns with this. Firstly, as many feminist theologians have demonstrated over decades, churches themselves often remain entangled in sociologies of gendered power. The munex triplex roles for the church of prophet, priest and king, possibly despite their original intentions, remain innately and structurally power-laden and androcentric. The king remains king, even if he admits that sometimes he is not perfect; the priest must remain beyond reproach, in order to perform his priestly tasks; the male prophet turns their angry speech beyond themselves. In this way there is a danger that churches, in light of \#metoo, will merely join the chorus of those seeking to find someone else to blame, as seen in the April 2019 public letter by the former Pope Benedict, blaming the sexual revolution for clerical sexual abuse (BBC News 2019). 
The church can remain structurally powerful in relation to individuals in its care and within wider society, while some of its power-laden representatives claim the rhetoric and symbols of vulnerability (the shepherd's crook, the kneeling foot-washer, the crucified God), as a humble veneer behind which invisible structural power to abuse and to shelter abusers unchallenged, may persist. Secondly, Koopman's focus is on a communicative vulnerability, where Christians are called to be vulnerable as God is vulnerable - by being open to the wounds and suffering of the world, the contingencies and tragedies of life, and the possibilities of being hurt - as Jesus did. While this is clearly an important call, focusing on this alone may unwittingly draw attention away from the heart of the prophetic critique as articulated by the 1983 Kairos Document (Kairos Theologians 1986), as one addressed primarily to the church and not by the church. It called churches to confess and repent of theologies that underpinned the harmful apartheid status quo, and to admit its own moral vulnerabilities and complicity in distorted theologies that misrepresented God. This prophetic witness is in line with Walter Bruggeman's (1987) claim that, prophetic critique is firstly self-critique, (my people, tribe, and faith), not only a courageous voice to challenge structures outside, but also an indictment of those within.

If Christians are to be part of a faithful church, as both Vosloo and Koopman suggest, the question arises: Faithful to whom or to what? It may be theologically simple to merely say: faithful to God - but what does this mean in practice? Where is the God located to whom the church's acts of fidelity are to be addressed? If God's body is identified with the crucified bodies of the women and children whose primary experience of the church is that of sexual abuse, our first act of fidelity must surely never be to protect the reputation of the church, but to listen to their voices and hear the hidden truths of our own church failures, both historically and in contemporary times. I suggest that this involves a theological task to dismantle ecclesiologies of church perfection where churches are presented as institutional saviours and providers of forgiveness to sinful individuals. The shadow side of idealising the church is perpetuated in an ecclesiology of denial of the morally vulnerable complicity of its institution.

I do not suggest that either Vosloo or Koopman claim that the institutional church is perfect. The history of their specific church denominations within South Africa and the existence of the Belhar Confession adopted in 1986, show that they are well-aware of the need for ongoing embodied confession at church level around structural sins such as apartheid (Boesak 2013). But this is where a forthright theological acknowledgement of the ongoing ecclesiological complicity of the church in other forms of moral complicity must also publicly witness to its long history of moral failures as the place of concrete lament from which all genuine hopes for a liberating approach must emerge. Ecclesiologies of vulnerability must include, but also go beyond merely embracing a solidarity with the vulnerability of the victims. It also requires public confessional witness to the perpetration, silence and institutional complicity of churches, which requires a multi-faceted understanding of vulnerability, to which I now turn.

\section{Towards a kairos ecclesiology of moral vulnerability}

South Africa's long history of kairos theology was developed in relation to the various challenges of many churches' complicity in apartheid (Nolan 1994). In recent years, it has been reclaimed in new ways in South Africa and around the world as a way of doing theology differently and disruptively not just as a prophetic theology of bold speech by the churches addressed to those outside the church, but as a peoples theology addressed primarily to the churches and calling them to theological confession as a 'moment of truth' (Kairos Document 1986). Reclaiming this trajectory in new ways is important when considering what solidarity with the \#metoo sexual abuse crisis means. It may involve churches resisting the temptation to turn their critical gaze outwards, to blame the secular world and social ills, and to offer a moral critique from above that keeps their own hands clean. Instead it involves embodied confession where churches relinquish their desire to hold a moral high ground and offer a contribution from a place of shared vulnerability as an act of prophetic witness in weakness.

To assist in this task, I turn to the Dutch ecclesiological scholar, Koffeman's (2009) writing at the end of the 'Decade to Overcome Violence' instituted by the World Council of Churches from 1998 to 2009. Koffeman notes that one of the goals of this project was (WCC 2006):

... to challenge the churches to overcome the spirit, logic and practice of violence, to relinquish any theological justification of violence, and to affirm anew the spirituality of reconciliation and active non-violence.

This Decade explicitly called churches to 'acknowledge their own vulnerability', and Koffeman rightly asks what this means in practice. He points out the danger that vulnerability is only confessed at an abstract level, and that therefore an idealised picture of the church is perpetuated. He notes that recent dialogues between churches have acknowledged that this idealised image of the church often bears little resemblance to the visible reality of the Church as it has journeyed and struggled through history' (Koffeman 2009:405). In so doing, he highlights and engages the various grey areas of church life and its institutionalised patterns of silence, bureaucracy and inertia, he argues can lead to complicity in the face of specific abuses.

Koffeman highlights four types of vulnerability. Two are primarily negative: physical vulnerability to being hurt or killed, and moral vulnerability to hurting others. Two are primarily positive: communicative vulnerability as a virtue open to learn from others, and compassionate vulnerability with the tragedies of life and solidarity with victims. For Koffeman, Koopman reflects a 'koinonia ecclesiology' where churches are called to participate in the life of God and 
God's missio dei. Therefore, because God is vulnerable (in Jesus), the church must be too. Being vulnerable becomes part of the church's mission in solidarity with the vulnerable and has only one clear meaning: that the church must always stand with the victims. While this aspect of vulnerability has much merit, I concur with Koffeman's concern that it can unwittingly distracts attention from the ambiguities of what the church is by focusing only on what it should be. This idealistic theological positioning can prevent the moral vulnerability of the church as an institution to directly and indirectly hurt others being taken seriously as a starting point from which all other forms of vulnerability must build.

Koffeman calls for a shift in ecclesiological theologies away from the various traditional ways that different denominations have historically created. He explains the binary tensions between the ideal and the actual church, including making a division between the visible and the invisible church being paradoxically both saint and sinner, the true and the false church, the church and its members, and the church now and the church as it will be. His concern is that these explanations may prevent people from theologically grappling with the hard evidence of the systematic sins of church institutions through time, and the theological ambivalences which this raises in practice. In this analysis, Koffeman highlights the binary rendering of ecclesiastical tensions in ways that can trap theologians within unhelpful categories, which are in urgent need of 'troubling'. Despite their usefulness at times, they run the risk of becoming theological 'get out of jail' clauses, which avoid serious engagement with the empirical reality, still seen by many as blasphemous that church institutions must be held accountable for their 'sins'. They enable the 'real' church to be positioned theologically as the one that forgives individual sin. The dark side of an ecclesiology of perfection can be ignoring, hiding, accommodating or explaining away its own sins, or refusing to engage sin's structural dimensions (Palm 2019a).

Koffeman takes us beyond a black and white binary of individualised victims and perpetrators only into a deeper theological reflection on what it means to see the church in its institutions and ideas as deeply entangled in forms of hierarchical violence that are sinful (Palm 2019a). For him, violence is not only something out there which the church must fix, but violence also forms part of church life. This is also a theme seen in Vosloo's exploration of Ugandan theologian, Emanuel Katongole, who shows how in various African contexts, churches become woven into the story of violence, and their buildings and leaders have in times become places of slaughter in places such as Rwanda, where ethnic divides trumped Christian solidarity (Katongole 2017). Ten years on from Koffeman's reflections, many churches remain enmeshed in direct and indirect ways, in multiple concrete violences against both children and women (Le Roux 2013; Palm 2019b). His argument for the acknowledgement of the moral vulnerability of the church, must shape all theologising today in relation to ecclesiology. Koffeman (2009:410) notes that, a church can be an accessory to, if not directly guilty of violence. It is the church's moral vulnerability that really challenges our ecclesiological concepts.' This offers an important insight into how churches can respond to \#metoo. Koffeman (2009:414), as a church lawyer, is concerned to ensure, that churches are held accountable and the need to bring in checks and balances. A commitment to do this in practice requires a theological grounding, which requires idealistic ecclesiologies to be treated with suspicion if safeguarding standards are to be taken seriously as a public task for the church. He argues:

... ecclesiology should always be related to the church in real life and in its specific context, not giving in to the temptation to idealize the church. Therefore, ecclesiology is necessarily a form of public theology. (Koffeman 2019:414)

\section{Embodying moral vulnerability}

Vosloo's emphasis on an ecclesiology of vulnerability leads him to suggest two further steps. In light of my analysis of moral vulnerability, this section turns briefly to these steps.

\section{Performing a politics of lament}

Vosloo (2019) draws on Ugandan theologian, Katongele's image of Jesus, weeping publicly, as in line with the longer prophetic trajectory of Jeremiah, forming a rupture with normalcy with a refusal to carry on as normal, which offers a possible way into a current day prophetic ministry of lament. It offers a public critique of the multiple politics of ethnic and gendered violence within which Katongele shows the global church remains entangled across the African continent. The historical violence of slavery, apartheid, coloniality and the 1994 killing fields of Rwanda, a Christian country, were all undergirded by theological justifications that trapped many churches into violent forms of complicity. These examples enable a recognition that contemporary sexual violence claims of \#metoo against churches, are not an anomaly in a generally morally clean church slate but are today's generation's manifestation of embodied resistance to their long and violent histories.

The need for lament, as an embodied part of public confession, is important. Churches must of course guard against the false tears of the Walrus in Lewis Carroll's Alice in Wonderland, while merely hiding entrenched, institutionalised and ideological patterns that lead more victims into danger, shame and silencing. Formal one-off confessions merely at top level, such as other pious words without embodied action can come across as surface hypocrisy as Reformed theologians of liberation such as Beyers Naude made clear in relation to challenging apartheid (Boesak 2013). However, this danger should not negate the need for the development of an alternative theological imagination based on a hope born from lament as Vosloo suggests. He points to the need to challenge what Jennings (2010:6) has termed, 'our diseased social imagination', as in need of healing. An ecclesiology that takes lament seriously will not hide behind the binary 
categories of an ecclesiology of denial that positions society as sick and the church as offering safe places of healing, but will also embrace the complex insight that the church itself is sick and in need of healing from its own diseased social imaginaries. Its reiteration of sinful and shameful taboos around sexuality often lead to a culture of hiding, abuse and secrecy that re-inscribes shame back onto the bodies of victims whilst moving the bodies of their abusers on into new places of abuse (Palm 2019b). My contention here is that genuine lament by churches must be explicit regarding its own institutionalised abuses. This requires churches to honestly relook at some of their own theological imaginaries, as imposed on others regarding sex and sexuality in light of increased evidence of its shameful and hypocritical realities. These can form tenatative first steps towards developing a new sexual theological imaginary.

South African feminist theologian, Denise Ackermann (2003:27), has called for many years for local churches to rediscover traditions of lament as Vosloo (2019) notes. She is concerned with the liberation of both the oppressed and the oppressor, and looks to the prophetic-messianic message of the Bible as containing a continuing self-critique, leading to a practical theology committed to action and advocacy that avoids a 'utopianism which deals only with eschatological dreams', and can focus on a liberating praxis (Ackermann 1993:36). Ackermann (2011:72) calls for relational praxis as an embodied concept where the needs of concrete bodies therefore form the primary context for obligation, asking the question: 'What will make for just relationships between us?'. ${ }^{3}$ For her, this entails the embrace of vulnerability (Ackermann 1994:45), as the starting place from where both hope and struggle can be embraced. For Ackermann, liberative praxis forms an ongoing struggle against the oppressive structures that exploit people and rob them of their full humanity. She, as I have done here, also calls for ongoing confession within and by churches of what has been done to the 'other'. This must include lament for and by, those whose experience of the church has not been welcoming, but abusive, as well as a lament by the church for their own complicity and perpetration. She warns against worship services that are unremittingly positive in tone. African songs of lament such as Senzeni $\mathrm{Na}$ [what have we done] may offer liturgical entry points into concrete confession of the church's complicit roles in sexual violence against vulnerable people, especially women and children.

\section{Moving towards an embodied performance}

Vosloo points towards embodied performativity as a form of resistance. The question remains urgent for churches today regarding how action should be taken, amidst the ruins of its institutional complicity and silence, in the face of the sexual abuse of women and children. How, to paraphrase South African liberation theologian, Boesak (2013), can the church bid farewell to innocence and go beyond its pious words to embody presence in action, to bear public witness and enact performative resistance? I suggest two possible contours for shaping action in this regard.

Firstly, in light of widespread denial and cover-ups in response to \#metoo, churches must 'come out' to publicly witness ongoingly and liturgically to their complicity, and open up to the precarious risks of vulnerability that come with allowing others to enter in and hold the church and its related theological institutions more accountable. To do this, churches will need to resist a performative triumphalism that positions it only as the solution and protector of victims, vulnerable primarily in its solidarity with the downtrodden victims, which enables it to claim a false innocence. Instead it is required to embrace a moral vulnerability that acknowledges its shared guilt and complicity, to be willing to expose its own flawed, imperfect institutional body, risk moral vulnerability, and disrupt cycles of hiding and silence that pushes blame elsewhere.

Secondly, they will have to radically rethink the performance of their ecclesiologies and liturgical and sacramental patterns in light of this flawed body, which remains constantly morally vulnerable to being complicit or abusive. What does it mean to rethink church rituals of communion, baptism and marriage in light of contemporary realities of sexual abuse? What practical implications does this have for pedagogies of Sunday schools, youth ministries and theological seminaries? What might it mean if on Good Friday, and as part of the 16 days of activism opposing violence against women and children each year, every single minister of the global church was required to wash the feet of those sexually abused within society and churches as a public act of confession and contrition. How do we listen not only to historical gospel readings of the Crucifixion, but to the current stories of victims crucified by clerical abuse and cover-up of abuse? What would it mean if the sermons currently preached on sexual victims in the Bible such as Tamar and Dinah in church lexicons were required to do so in light of the emerging evidence of church complicity today in sexual violence, and its cover-ups for the sake of family honour and church reputations? Resources to engage sacred texts more critically in relation to gender-based and sexual violence are beginning to be developed by para-Christian organisations and theologians (Siu-Maliko et al. 2019; West \& Zondi-Mazibele 2004). But these important resources often linger on the peripheral outskirts of ordinary church life with ministers and congregations terrified, defensive and illequipped to open this pandora's box. Instead, they are clinging to ecclesiologies of denial, rather than embracing those of courageous disruption.

Many power-laden patterns of being church in today's world will require radical, revolutionary reform regarding how they are structured if they are not to remain havens for those who seek to sexually dominate or control others as theologies of liberation have long suggested. This will involve a more radical contestation of how many churches currently imagine 
divine power in their doctrines, songs, liturgies and practices. A theological revolution begun by God in Christ, radicalises what needs to change in our societies, as well as how humans can image divinity together in life-enhancing mutual relationship. This is a far cry from the power-laden Lord, Master and Saviour male images of God, that continue to pepper our sacred texts, church traditions and religious practices and so often outwork into abusive ways of treating others as feminist scholars have long critiqued. The church is called to become a community that models radically egalitarian ways of behaving not in withdrawal from the 'world', but in prophetic witness with and in it. But to do so with integrity, it must confess its abusive complicity, and the reality that we all 'have a common vulnerability to culpability' (Boesak 2013:148), which has often been outworked in the shameful history of many Christian churches on human rights. Ways of understanding the church must confess the church's complicity in a fallen sinful condition in ways that also refuse to despair, and can point to the capacity to repent and change. If this is true, then it is only if the church can embody its own message that sinners can be redeemed and healed, which it will have the courage to go beyond its denials of culpability into performing the type of disruptive confessions, with which this article began. To do this, it must engage a hermeneutic of moral vulnerability within its own body to sit between spaces of crucifixion and the hopeful possibilities of its resurrection into new ways of being church. It is to this vulnerable theological dialectic of cross and resurrection that we finally turn.

\section{A vulnerability hermeneutic: The dialectics of cross and resurrection}

A complex, multi-faceted theological understanding of vulnerability must remain open to new interpretations. In this task, Van den Bosch's (2014) call for 'hermeneutics of vulnerability', as seen through the lens of the Holy Spirit, can help to call churches into a life-giving, truth-telling, and counter a tendency to only reclaim vulnerability as an asset connected to the divine. Practices of communicative vulnerability by churches, simultaneously require an embodied confession of its own complicity and moral vulnerability to be truthful. This is in a world that still normalises the 'denial of vulnerability' and seeks to create the illusion of control. Van den Bosch argues that ecclesial practices need to find ways to refute this denial and not perpetuate it. I suggest that this applies to the institutional denial of moral vulnerability regarding sexual abuse by many churches seeking to control and cover-up abuse in their midst as a form of 'damage control' by enacting a pretence that papers over its own moral vulnerability with a veneer of perfection. In this way, vulnerability discourse itself gets caught up in idealistic theologising by being seen only as 'the willingness to risk pain and suffering' enabling Christians to retain a moral high ground that identifies the church in solidarity with the victims, but shies away from also being identified with the perpetrators. Van den Bosch points to ways in which ritualised performances of churches in relation to children can offer new possibilities for enacting confession as prophetic witness, by seeing baptism as a communal expression of vulnerability, and as a form of resistance to all violence against children, alongside a commitment that church communities be sanctuaries in practice, and not just in theory for all children.

Vulnerability opens up humans and their social structures, both to the reality that we can be hurt by others and can be part of hurting others. Taking vulnerability seriously is not only to see it as the opposite of violence and oppression, but to also recognise it in our complex, complicit entanglement in sinful systemic patterns of violence and oppression (Palm 2019). This points to an ecclesiology from below in our shared need to admit the damage done by our faith institutions. By making room for this damage to be seen, churches open space for their own healing and transformation. As the Spirit groans in pain, and Jesus is humiliated on the cross, so must churches embrace the scandal of their complicity as a moral dimension of vulnerability to admit that the church is afflicted, and to be restored, will require ongoing practices of confession, radical repentance and turning around, if justification is to be reconnected to justice-creation, and embrace what Van den Bosch (2014:854) terms the 'vulnerability dialectics of cross and resurrection'. Much of the church is facing ugly crucifixion in the media and law courts for their failure to act in light of systematic sins of sexual abuse not as an innocent victim, but as a guilty enabler. Like the thief hanging next to Jesus, the church must own its role in the wounds inflicted on others because of its patterns of denial. Only once this pandora's box is opened, a costly hope can be built from the ruins of ecclesiological despair.

\section{Conclusion}

This article has interrogated an ecclesiology of vulnerability to note the danger of only seeing the church as the solution called to fruitful solidarity with the vulnerability of others. Framing vulnerability only in positive ways runs the risk of retaining an overly idealistic ecclesiology where the church models a kenotic vulnerability that stands alongside the victims as the place where God stands. While this is clearly an important part of their task, it may hide a second, harder task for churches, namely also standing in the place of perpetration, silence, complicity, failure and accepting their own moral vulnerability. Without this second task, church claims from on high of solidarity with new victims may ring hollow, especially to those it has damaged.

Vosloo's threefold call to the church of vulnerability, lament and performance as resistance can be made concrete in relation to sexual violence only if churches can move from an ecclesiology of denial to an ecclesiology of disruption. This can open space to re-imagine the power-laden images of God that often still lie beneath stories in sacred texts within which sexual violence and its justifications remains entangled. Promising approaches such as the contextual Bible study methodologies of the stories of Tamar and Hagar have begun 
to travel to different corners of the world and demonstrate the effect, which radical theological reimagining can have within congregations around the realities of gender-based and sexual violence and the underpinning religiously legitimated social norms that can underpin them.

What will it mean to both confess and profess that God enters the world as a child vulnerable to sexual abuse? At its heart, the Christian story suggests that it is from the crucified below and through the groaning Spirit that disrupts all injustice that new life for the body of the church itself will come. Brueggemann (1987) reminds us that the prophetic imagination arises first from a listening to and an accompanying of the silenced voices of pain in present times. Christians can be too quick to jump forward to hope as the 'answer' - offering a resurrection coda that is at risk of negating current suffering and can foreclose its ongoing protest. Vulnerable people's voices of lament at the abusive use of their bodies, both in biblical times and today, must be held, remembered and included in our performance of church. This must be shaped by ecclesiologies of moral vulnerability if contemporary stories of sexual violation and exploitation of bodies are to be given voice through the radical reimagining of stories of sexual violence within Christian sacred texts such as Tamar, Hagar and Dinah in ways that more faithfully remember a God who says \#metoo.

\section{Acknowledgement Competing interest}

I declare that I have no financial or personal relationships which may have inappropriately influenced me in writing this article.

\section{Author's contributions}

I declare that I am the sole author of this research article.

\section{Ethical consideration}

This article followed all ethical standards for a research without direct contact with human or animal subjects.

\section{Funding information}

This research received no specific grant from any funding agency in the public, commercial, or not-for-profit sectors.

\section{Data availability statement}

Data sharing is not applicable to this article as no new data were created or analysed in this study.

\section{Disclaimer}

The views and opinions expressed in this article are those of the authors and do not necessarily reflect the official policy or position of any affiliated agency of the authors.

\section{References}

Ackermann, D., 1993, 'Critical theory, common action and liberating praxis', Journal of Theology for Southern Africa 82(1), 21-36.

Ackermann, D., 1994, 'Women, religion and culture', Missionalia 22(3), 100-110.

Ackermann, D., 2003, After the locusts, letters from a landscape of faith, Eerdmans, Grand Rapids, MI.

Ackermann, D., 2011, 'Becoming more fully human', in J. de Gruchy (ed.), The humanist imperative for South Africa, pp. 67-76, Sun Press, Stellenbosch.

Blue Like Jazz, 2013, DVD, Christian Art Media, South Africa.

Boesak, A., 2013, 'The time for pious words is over: Beyers Naude, decision, conscience and courage in the struggle for justice', in M.-A. Plaatjies-Van Huffel \& R. Vosloo (eds.), Reformed churches in South Africa and the struggle for justice: Remembering 1960-1990, pp. 213-225, Sun Press, Stellenbosch.

Brueggemann, W., 1987, Hope within history, John Knox Press, Westminster.

BBC News, 2019, 'Ex-Pope Benedict XVI blames 1960s revolution for sex abuse', 11 April, viewed 06 March 2019, from https://www.bbc.com/news/world-europe-47898562.

Halpin, P., 2018, 'Factbox: Reports into abuse in the Irish Catholic Church', Reuters News, 20 August, viewed 08 April 2019, from https://www.reuters.com/article/ us-pope-ireland-abuse-factbox-idUSKCN1L51J0

Jennings, W., 2010, The Christian imagination: Theology and the origins of race, Yale University Press, New Haven, CT.

Kairos Theologians, 1986, The Kairos Document: Challenge to the church, Skotaville Publishers, Braamfontein.

Katongole, E., 2017, Born from lament: The theology and politics of hope in Africa, Eerdmans, Grand Rapids, MI.

Koffeman, L., 2009, 'The vulnerability of the church - Ecclesiological observations', Scriptura 102, 404-415. https://doi.org/10.7833/102-0-603

Koopman, N., 2008, 'Vulnerable church in a vulnerable world? Towards an ecclesiology of vulnerability', Journal of Reformed Theology 2(3), 240-254. https://doi.org/ 10.1163/156973108X333731

Le Roux, E., 2013, Sexual violence in South Africa and the role of the church, Research Report, Unit for Religion and Development Research, Stellenbosch University, viewed n.d., from https://blogs.sun.ac.za/urdr/theory-building/

Le Roux, E. \& Palm, S., 2018, What lies beneath? Tackling the roots of religious resistance to ending child marriage, Research Report, GirlsNotBrides, London.

News24, 2018, 'You call them tata and they treat you like a piece of meat' - Methodist church protester speaks out', 31 March, viewed 06 April 2018, from https://www. news24.com/Video/SouthAfrica/News/you-call-them-tata-and-they-treat-you-likea-piece-of-meat-methodist-city-mission-protester-speaks-out-20180131.

Nolan, A., 1994, 'Kairos theology', in J. de Gruchy \& C. Villa-Vicencio (eds.), Doing theology on context: South African perspectives, pp. 212-218, Orbis, New York.

Palm, S., 2019a, 'Re-imagining sin: Nurturing youth spiritualities for social justice', in J. Claassens, C. van der Walt \& F. Olojede (eds.), Teaching for change: Essays on pedagogy, gender and theology in Africa, pp. 113-132, Sun Press, Stellenbosch.

Palm, S., 2019b, Scoping study on faith actors' involvement in the prevention, elimination and perpetuation of violence against children, Expert consultation report, Joint Learning Initiative for Local Faith Communities, Washington, DC.

Palm, S. \& Le Roux, E., 2018, 'Households of freedom? Faith's role in challenging gendered geographies of violence in our cities', in S. de Beer (ed.), Just faith: Glocal responses to planetary urbanization, pp. 135-163, AOSIS Online, South Africa.

Progressio., 2016, The price of womanhood: Girls and young women's sexual and reproductive health and rights in Zimbabwe, Catholic Institute for Education, reproductive

Prosser, C., 2016, 'Child sexual abuse royal commission: Salvation Army "failed to protect children" from sexual abuse', viewed 05 May 2019, from https://www. abc.net.au/news/2016-09-12/salvation-army-failed-to-protect-children-royalcommission-finds/7835784

Ritchie, G., 2018, 'Anglican church to "strengthen procedures" in light of sexual abuse allegations', Mail and Guardian, 22 March, viewed 06 April 2019, from https:// mg.co.za/article/2018-03-22-anglican-church-to-respond-better-to-sexual-abuse.

Rutledge, K. \& Eyber, C., 2019, Scoping study on faith actors' involvement in the prevention, elimination and perpetuation of violence against children, Literature Review, JLILFC Ending Violence Against Children Hub, Queen Margaret University, London.

Siu-Maliko, M., Beres, M., Blyth, C., Boodoosingh, R., Patterson, T. \& Tombs, D., 2019, Church responses to gender-based violence against women in Samoa, New Zealand Institute for Pacific Research, Auckland.

Smit, D., 2007, 'On the impact of the church in South Africa after the collapse of the apartheid regime', in E. Conradie (ed.), Essays in public theology, collected essays: Dirk Smit, pp. 57-75, Sun Press, Stellenbosch.

Van den Bosch, D., 2014, 'Spirit, vulnerability and beauty: A pneumatologica exploration', NGTT 55(3 \& 4), 835-857. https://doi.org/10.5952/55-3-4-668

Vosloo, R., 2019, 'Prophetic witness in weakness', In die Skriflig 53(4), a2400. https:// doi.org/10.4102/ids.v53i4.240

West, G. \& Zondi-Mabizele, P., 2004, 'The Bible story that became a campaign: The Tamar campaign in South Africa and beyond', Ministerial Formation July, 4-12.

World Council of Churches, 2006, Mid-term of the ecumenical decade to overcome violence 2001-2010: Churches seeking reconciliation and peace, WCC Publication, Geneva.

Yang, A., 2019, 'When churches don't believe victims, they commit abuse', CBE International, viewed 09 July 2019, from https://www.cbeinternational.org/ blogs/when-churches-do-not-believe-victims-they-commit-abuse\#.XZNaPtsbGgO. 